\title{
LETTER FROM THE EDITOR: A SPECIAL REQUEST
}

This letter is an unabashed appeal to the members of the Society for the Study of Early China and other readers of Early China, for donations, large or small. You can make these, as well as join the Society or renew your membership subscription, at www.cambridge.org/core/ membership/ssec. Our field is flourishing with an abundance of new materials and new ideas, and it is a particularly exciting moment in its development. This journal plays an important-I think critical—role in that development, especially in the West. I am very proud of what we have accomplished in the last decade, but the Society needs more financial support if we are to sustain the journal at this level. Those of us who have been active in the field since Early China was founded more than four decades ago know that the journal, having begun as an informal newsletter, has always depended upon volunteer labor and membership subscriptions. However, the amount of labor needed to maintain the level of professionalism that we have now achieved may not be obvious to those of you not directly involved in the work. As for younger scholars, I suspect that the longevity and professional quality of Early China makes it look like an established institution that does not need their help. Nevertheless, unlike other journals of this quality and importance, we do not have any endowment or any institutional support. The Society is nothing more than its members, and we need your assistance.

Since we signed on to JSTOR and began to be published by Cambridge University Press in 2014, our membership subscription fees have been supplemented by a share of the profits from the much wider online distribution of the journal. These are very helpful, but they are not sufficient to hire the regular assistance that the editor now needs to deal with the complexity of publishing the journal in its current form. We need a more solid financial foundation, as well as the active support of our membership. And the more solid this foundation is, the more the Society can do besides publishing the journal, including reviving in-person conferences and our monograph series.

The contents of this volume of Early China (44), with its rich, innovative, and diverse articles, readily serves as representative of the quality of the journal There are ten research articles. The authors are based on three continents and range from newly minted Ph.D.'s to well-known senior scholars. They include: "The Beginning of Cultural Memory Production 
in China and the Memory Policy of the Zhou Royal House during the Western Zhou Period" by Maria Khayutina; "Decorated Models, Replication, and Assembly Lines for Bronze Industrial Production in 500 в.C.E. China" by Li Kin Sum and colleagues; "The Han River as the Central Axis and the Predominance of Water: Questioning the Claim of 'No Chu-related Traits' in the View of Terrestrial Space in the Rong Cheng shi manuscript (fourth century B.C.E.)" by Vera Dorafeeva-Lichtmann; "Molecular Incoherence, Continuity, and the Perfection of the Laozi," by David Lebovitz; "The Performance of Silence in Early China: The Yanzi chunqiu and Beyond" by Ai Yuan; "Categorizing Laborers: Glimpses of Qin Management of Human Resources from an Administrative Document from Liye, Hunan Province," by Tsang Wing Ma; "The Promulgation of Law in Qin and Western Han China," by Li Jingrong and Chen Songchang; "Further Considerations for the Authentication of the Peking University Cang Jie pian: With Brief Digression on the So-Called 'Han Board' Witness," by Christopher J. Foster; and "Subtle and Dangerous: The Crossbow Trigger Metaphor in Early China," by Boqun Zhou.

Besides these articles, this volume also includes an invaluable review article by Olivier Venture on excavated inscriptions and manuscripts published from 2008 to 2018 , which highlights lesser-known discoveries and briefly explains their importance. The author has agreed to update it regularly and we welcome other such informative review articles. We also commemorate the Polish-Russian sinologist, Stanisław Kuczera and the Chinese archaeologist, Zhang Changshou 張長壽 with obituaries by Sergey Dmitriev and Li Feng, respectively. And you can keep up to date on the latest in your field of interest with our Annual Bibliography and Dissertation Abstracts compiled by Wen-Yi Huang.

I am pleased to announce that the next volume of Early China will be dedicated to Michael Loewe on his hundredth birthday and include a number of invited articles relevant to his research, guest-edited by Michael Nylan.

To donate to the Society for the Study of Early China, go to www. cambridge.org/core/membership/ssec.

Sarah Allan

Berkeley, California September 20, 2021 